\title{
How to Increase Market Capitalization in Eurasian Markets?
}

\author{
Asst. Prof. Dr. Sitkı Sönmezer (Beykent University, Turkey) \\ Assoc. Prof. Dr. İlyas Sözen (Beykent University, Turkey)
}

\begin{abstract}
The objective of the study is to put forth the difference between the characteristics of Eurasian markets and the developing country markets and test convergence hypothesis based on market capitalization. Factors that obstacle foreign investments into these markets are assessed and possible ways to eradicate the gap between these markets is discussed. Market based variables such as number of listed companies is combined with other variables that may shed light to the investment environment to have a better understanding of the factors affecting market capitalization. Multi regression analysis are done for the markets that succeed in coaxing foreign investors and domestic investors to their market and the study highlights the factors that countries need to focus in order to converge to the successful ones.
\end{abstract}

\section{Introduction}

Stock markets may play a key role in fostering growth in Eurasian countries as they may provide a source of external financing for market participants. Obviously, external financing may be used to invest in new projects, plant, equipment etc. It is evident from the comparatively low trading volume levels of these countries that domestic interest in stock markets is insufficient. Thus, characteristics of these markets have to be rearranged to coax foreign investors who have interest in these markets but also fears regarding with these markets have to be mitigated. This study examines the factors that may trigger the fears of investors and aims to indicate the areas where to advance for the regulators.

Convergence of Eurasian markets with the developed markets may accelerate with rapid advancements in the financial sector and this study uses Market Capitalization as an indicator of convergence which is computed by multiplying the share price of listed companies with the number of shares outstanding. Thus, Market Capitalization may increase twofolds; price increases in the stock prices and increases in the number of shares.

Consequently, it is essential to prioritize factors affecting share prices as number of shares is arbitrary and prices are adjusted proportionately by the increase in shares outstanding. It is clear that countries aiming to increase their shares prices, should increase the demand for their shares. Intuitively, demand may increase by increasing the number of demanders. These markets need to attract more investors either domestic or foreign but the latter is more promising as they are more affluent most of the time. So it is clear whom to target for increasing market capitalization and which factors shall be improved to attract them is the focus of this study.

Financial Markets are center of attraction for high net worth investors and funds. However, these investors eye out well-functioning markets where price and volume information is accurate and timely provided; liquidity is present in terms of marketability, price continuity and depth; where internal efficiency is present where transaction costs are low and where external efficiency is present where prices adjust to new information as fast as well functioning developed markets.

Liquidity in a market may be crucially important for investors as they want to exit a market quickly as well as they enter a market. In that sense, lack of marketability, lack of the ability to sell the stock quickly, may cause investors avoid that particular investment. Similarly, price continuity, which can be described as prices not deviating from one transaction to the subsequent transaction when there is no new information regarding with the security, is another essential factor that may influence investing decisions.

Even if investors can market their securities, they need to be assured that the price they are going to convert their security into cash will not differ significantly from the recent transaction's price. Intuitively, price continuity has to be present in a market that aims to attract foreign investors as one of the reasons that foreign investors enter a market is for possible higher returns. When they are forced to sell at lower levels, their profit margins will surely diminish and this fact may avoid them from investing.

From liquidity perspective, depth may also important. In a market where lots of buyers and sellers that are willing to trade the securities at the current price and also at prices below and above the current price may be a factor attracting foreign investors who want to trade in larger scales. Similarly, lack of depth may reduce profit margins as prices will possibly change significantly and adversely when no counter party is found.

Finally, trust in the financial system, ability to find relevant and accurate financial information, robust and fair legal system and good faith and character of intermediaries, in terms of fronting, kickbacks etc. may all be determinants of participation in a market but some of the above mentioned factors are beyond the scope of this study due to lack of information.

The objective of this study is to provide evidence that whether Eurasian markets may significantly attract foreign investors or not and to determine which factors might have increased the foreign participation rates. 
Moreover, what external factors may convince foreign investors to invest in these markets and what conditions may affect their decision is discussed in this study. It is evident that interest rates are at lower levels and growth rates are not promising in the developed countries in recent times. As a result, funds flow from these markets to the emerging ones to pursue higher returns despite higher risks.

\section{Related Theories and Literature Review}

Literature regarding with market capitalization and foreign funds are mostly interrelated but classified separately in this study.

\subsection{Market Capitalization}

Convergence Hypothesis examines the possibility of low growth companies catching up the gap with the countries that have higher economic growth (Baumol, 1986). This hypothesis is analyzed in depth by economic growth in the macroeconomic literature but the focus is diverted to financial markets recently. Some studies have examined convergence in terms of financial development via banking sector (Fung, 2009), some studies have searched convergence in terms of stock markets. (Narayan, Mishra and Narayan, 2011). They show evidence that ten to fifteen years is needed for convergence take place.

The significant positive correlation between stock market development and economic growth are evidenced in the literature (Atje \& Jovanovich, 1993; Levine \& Zervos, 1998). Hussain, Rehman and Rza (2012) similarly provide evidence that stock market development has led to economic growth in Pakistan.

An efficient market with a robust financial sector that provides liquidity are assumed to have a crucial importance in economic performance The liberalization and deregulation of the financial system enabled foreign capital to flow to these markets. (Das, 2014)

\subsection{Foreign Equity Inflows}

There are various theories regarding with why foreign capital may flow to other markets and they aim to explain the rationale behind equity flows. Some theories try to explain the reasons why foreign inflows take place, namely, base broadening theory and omitted variables theory; some try to explain the rationing of these flows such as feedback theory and price pressure hypothesis.

Among these theories, base broadening hypothesis is a model that indicates how broadening the investor base for a stock or a market, may increase stock values permanently through risk pooling (Merton, 1987). Foreign investors are well aware that when they decide to enter a market, they may have the power to move the prices of equities at a higher price than the current prices and sustain the price level of the equity prices as the market will now be aware of the presence of the new comers and the prices may be adjusted with this reality. Foreign investors may examine markets to exploit an opportunity as such. Tilmann (2013) have provided evidence that capital inflows affect asset prices by using a panel VAR.

Omitted variables hypothesis states that despite a significant correlation between equity inflows and security prices, additional factors may play a significant role in explaining the correlation. In this study, it is aimed to put forth the possible additional factors that may help the academicians that test this hypothesis. Earlier studies have used returns of Morgan Stanley World Price Index, S\&P 500, Mexican Bills, dollar-peso exchange rate, stock price volatility and percent growth in aggregate earnings forecasts as omitted variables. (Clark and Berko, 1996) Similarly, the hypothesis may well be adapted to determine the relationship among foreign equity inflows and other factors.

The feedback theory suggests that investors evaluate the recent information on prices and make transactions according to the recent information. Eurasian markets should reduce the obstacles that may cause foreign investors to question the completeness and accuracy of the information they provide.

When foreign investors trade with feedback, there are two main forms; a positive feedback strategy suggests that foreign investors sell when there is a decline in the market and they buy stocks when the market is rising. The direction of their trade may move the prices of securities to extremes and the host country should monitor closely to take corrective actions if necessary.

Regarding with the increased liquidity provided by the foreign inflows, markets become more efficient as foreign funds request stricter disclosure requirements which may enhance the dissemination process of new information and transparency (Bae, Bailey and Mao 2006). Levine and Zervos (1998) also found that stock markets dissemination of information.

Moreover, when there are foreign equity flows into a developing market, they lead new information to be incorporated into prices more quickly (Todea and Pleşoianu, 2013). Similarly, high transaction costs and low liquidity levels may extend the time period of the above mentioned incorporation process (Schatberg and Rieber, 1992). Todea and Pleşoianu (2013) have analyzed the effects of foreign portfolio investments on stock market efficiency of Central Eastern European Countries and show evidence that they play a positive role in the degree of efficiency. 
Choong, Baharumshah, Yusop and Habibullah (2010) show evidence that countries that have threshold level of stock market development, are affected positively from capital inflows. As a stock market indicator they have used total stock value to GDP ratio. They argue that transformation of local stock markets is obligatory to handle equity flows or host countries may face detrimental effects.

\section{Data and Methodology}

35 countries data are gathered from World Bank databases for the years 2002-2012. These countries, namely, Argentina, Armenia, Brazil, Bulgaria, Chile, China, Colombia, Croatia, Cyprus, Czech Republic, Estonia, Georgia, Greece, Hungary, India, Indonesia, Kazakhstan, Korea, Rep., Kyrgyz Republic, Latvia, Lithuania, Macedonia FYR, Malaysia, Mexico, Peru, Philippines, Poland, Romania, Russian Federation, Slovak Republic, Slovenia, Thailand, Turkey, Ukraine, Venezuela, RB. Some countries are eliminated due to lack of information. Our dependent variable is the market capitalization, and independent variables are namely, number of listed domestic companies, Stocks traded-turnover ratio in percentages, Foreign direct investments in US dollars, Real interest rates in percentages, annual GDP growth, The Chinn-Ito index (KAOPEN), Voice and Accountability, Political Stability and Absence of Violence/Terrorism and Control of Corruption.

Multi regressions are run annually and significant factors affecting market capitalization are analyzed. The form of the multiregression used is as follows:

$\mathrm{Y}_{\mathrm{t}}=\mathrm{B}_{0}+\mathrm{B}_{1} \mathrm{Y}_{1}+\mathrm{B}_{2} \mathrm{Y}_{2}+\ldots .+\mathrm{BnYn}+\mathrm{u}_{\mathrm{t}}$

where,

$B_{o}$ is the intercept and the coefficients belongs to the pertaining independent variables as in $B n Y n, t=1 \ldots . . T$ is the time index and $\mathrm{i}=1, \ldots, \mathrm{N}$ is the country index, $\mathrm{Y}_{\mathrm{t}}$ is the explained variable, market capitalization.

Independent variables are explained here below (WB Data, 2014):

- Portfolio equity, net inflows (PENI \$): Portfolio equity includes net inflows from equity securities other than those recorded as direct investment. These flows are mainly composed of shares, American Depository Receipts (ADRs), global depository receipts or European Depository Receipts (EDRs), and direct purchases of shares in local stock markets by foreign investors.

- $\quad$ Foreign direct investment (FDI), net inflows (\$): Foreign direct investment are the net inflows of investment to acquire a lasting management interest (10 percent or more of voting stock) in an enterprise operating in an economy other than that of the investor.

- Market capitalization (MC \$): is the sum of the product of each listed share price and the number of shares outstanding of that particular share.

- Listed domestic companies (LDC): total listed domestic companies are the domestically incorporated companies listed on the country's stock exchanges at the end of the year. Investment companies, mutual funds, or other collective investment vehicles are excluded.

- $\quad$ Stocks traded, turnover ratio (STTR \%): Turnover ratio is the total value of shares traded during the period divided by the average market capitalization for the period. Average market capitalization is calculated as the average of the end-of-period values for the current period and the previous period.

- Inflation (INF): Consumer Price Index

- Real interest rate (RINT): Real interest rate is the lending interest rate adjusted for inflation as measured by the GDP deflator.

- GDP growth: Annual percentage growth rate of GDP at market prices based on constant local currency. Aggregates are based on constant 2005 U.S. dollars. GDP is the sum of gross value added by all resident producers in the economy plus any product taxes and minus any subsidies not included in the value of the products. It is calculated without making deductions for depreciation of fabricated assets or for depletion and degradation of natural resources.

- Voice and Accountability (VA): capturing perceptions of the extent to which a country's citizens are able to participate in selecting their government, as well as freedom of expression, freedom of association, and a free media.

- $\quad$ Political Stability and Absence of Violence/Terrorism (PV): capturing perceptions of the likelihood that the government will be destabilized or overthrown by unconstitutional or violent means, including politicallymotivated violence and terrorism.

- Control of Corruption (CC): capturing perceptions of the extent to which public power is exercised for private gain, including both petty and grand forms of corruption, as well as "capture" of the state by elites and private interests

- The Chinn-Ito index (CII) is an index measuring a country's degree of capital account openness. The index was initially introduced in Chinn and Ito (Journal of Development Economics, 2006). KAOPEN is based on the binary dummy variables that codify the tabulation of restrictions on cross-border financial transactions 
reported in the IMF's Annual Report on Exchange Arrangements and Exchange Restrictions Chinn-Ito Index, 2014).

\section{Findings}

While trying to determine the factors influencing market capitalization, it is realized that factors vary from year to year as multi regressions are run for each year. The descriptive statistics of the data are given in Table 1 . significant factors in explaining the change in market capitalization are given in Table 2.

\begin{tabular}{|c|c|c|c|c|c|c|c|c|c|c|c|c|}
\hline & \multicolumn{2}{|c|}{2002} & \multicolumn{2}{|c|}{2003} & \multicolumn{2}{|c|}{2004} & \multicolumn{2}{|c|}{2005} & \multicolumn{2}{|c|}{2006} & \multicolumn{2}{|c|}{2007} \\
\hline & mean & st. Dev. & mean & st. Dev. & mean & st. Dev. & mean & st. Dev. & mean & st. Dev. & mean & st. Dev. \\
\hline MC & $5,15 \mathrm{E}+10$ & $9,12 \mathrm{E}+10$ & $7,70 \mathrm{E}+10$ & $1,37 \mathrm{E}+11$ & $7,77 \mathrm{E}+08$ & $1,74 \mathrm{E}+09$ & $1,32 \mathrm{E}+11$ & $2,14 \mathrm{E}+11$ & $2,28 \mathrm{E}+11$ & $4,67 \mathrm{E}+11$ & $4,49 \mathrm{E}+11$ & $1,14 \mathrm{E}+12$ \\
\hline PENI & $2,87 \mathrm{E}+08$ & $7,25 \mathrm{E}+08$ & & & & & & & & & & \\
\hline FDI & & & & & $6,22 \mathrm{E}+09$ & $1,12 \mathrm{E}+10$ & $8,54 \mathrm{E}+09$ & $1,75 \mathrm{E}+10$ & & & & \\
\hline LDC & $5,55 \mathrm{E}+02$ & $1,22 \mathrm{E}+03$ & $5,48 \mathrm{E}+02$ & $1,18 \mathrm{E}+03$ & $5,14 \mathrm{E}+02$ & $1,03 \mathrm{E}+03$ & $5,12 \mathrm{E}+02$ & $1,01 \mathrm{E}+03$ & $4,78 \mathrm{E}+02$ & $9,17 \mathrm{E}+02$ & $4,98 \mathrm{E}+02$ & $9,37 \mathrm{E}+02$ \\
\hline STTR & $5,28 \mathrm{E}+01$ & $9,15 \mathrm{E}+01$ & $3,87 \mathrm{E}+01$ & $5,45 \mathrm{E}+01$ & $4,27 \mathrm{E}+01$ & $5,27 \mathrm{E}+01$ & $4,02 \mathrm{E}+01$ & $4,59 \mathrm{E}+01$ & $4,30 \mathrm{E}+01$ & $4,39 \mathrm{E}+01$ & $4,84 \mathrm{E}+01$ & $5,12 \mathrm{E}+01$ \\
\hline INF & $6,47 \mathrm{E}+02$ & $3,79 \mathrm{E}+03$ & & & $6,26 \mathrm{E}+02$ & $3,68 \mathrm{E}+03$ & $4,61 \mathrm{E}+02$ & $2,70 \mathrm{E}+03$ & $3,95 \mathrm{E}+02$ & $2,31 \mathrm{E}+03$ & $5,68 \mathrm{E}+00$ & $3,09 \mathrm{E}+00$ \\
\hline RINT & $9,37 \mathrm{E}+00$ & $9,08 \mathrm{E}+00$ & $7,27 \mathrm{E}+00$ & $9,17 \mathrm{E}+00$ & $3,94 \mathrm{E}+00$ & $1,15 \mathrm{E}+01$ & $4,79 \mathrm{E}+00$ & $9,61 \mathrm{E}+00$ & $4,39 \mathrm{E}+00$ & $8,01 \mathrm{E}+00$ & $3,73 \mathrm{E}+00$ & $8,19 \mathrm{E}+00$ \\
\hline GDP & $3,82 \mathrm{E}+00$ & $4,34 \mathrm{E}+00$ & $5,53 \mathrm{E}+00$ & $3,72 \mathrm{E}+00$ & & & $6,17 \mathrm{E}+00$ & $3,03 \mathrm{E}+00$ & $7,14 \mathrm{E}+00$ & $2,60 \mathrm{E}+00$ & $7,27 \mathrm{E}+00$ & $2,95 \mathrm{E}+00$ \\
\hline CII & $3,47 \mathrm{E}-01$ & $1,32 \mathrm{E}+00$ & $5,31 \mathrm{E}-01$ & $1,27 \mathrm{E}+00$ & $7,10 \mathrm{E}-01$ & $1,27 \mathrm{E}+00$ & 7,70E-01 & $1,29 \mathrm{E}+00$ & $8,33 \mathrm{E}-01$ & $1,36 \mathrm{E}+00$ & $9,30 \mathrm{E}-01$ & $1,43 \mathrm{E}+00$ \\
\hline PV & $-8,46 \mathrm{E}-02$ & $9,02 \mathrm{E}-01$ & $-1,73 \mathrm{E}-01$ & $9,86 \mathrm{E}-01$ & $-2,65 \mathrm{E}-01$ & $8,63 \mathrm{E}-01$ & & & $-1,54 \mathrm{E}-01$ & $8,53 \mathrm{E}-01$ & $-9,24 \mathrm{E}-02$ & $8,11 \mathrm{E}-01$ \\
\hline $\mathrm{CC}$ & $-9,63 \mathrm{E}-02$ & 7,50E-01 & $3,14 \mathrm{E}-03$ & $6,98 \mathrm{E}-01$ & $-9,14 \mathrm{E}-03$ & $7,00 \mathrm{E}-01$ & $-8,57 \mathrm{E}-04$ & $7,03 \mathrm{E}-01$ & $-1,83 \mathrm{E}-02$ & 6,96E-01 & $-1,61 \mathrm{E}-02$ & 6,81E-01 \\
\hline $\mathbf{R}^{2}$ & \multirow{2}{*}{\multicolumn{2}{|c|}{$\frac{0,54}{0,37}$}} & \multicolumn{2}{|c|}{0,36} & \multicolumn{2}{|c|}{0,46} & \multicolumn{2}{|c|}{0,69} & \multicolumn{2}{|c|}{0,45} & \multicolumn{2}{|c|}{0,61} \\
\hline $\operatorname{adj} . R^{2}$ & & & & 2 & 0 & 3 & & 6 & 0, & 28 & 0, & 49 \\
\hline \multirow[t]{3}{*}{ F Test } & & & \multicolumn{2}{|c|}{2,82} & &, 29 & \multicolumn{2}{|c|}{2,68} & \multicolumn{2}{|c|}{4,78} \\
\hline & & & 2009 & & 2010 & \multicolumn{2}{|c|}{2011} & 2012 & \multirow{2}{*}{\multicolumn{2}{|c|}{ st. Dev. }} & & \\
\hline & \multicolumn{2}{|c|}{\begin{tabular}{l|l|l}
\multicolumn{2}{c|}{2008} & \\
mean & st. Dev.
\end{tabular}} & mean & st. Dev. & mean & \begin{tabular}{|l|} 
st. Dev. \\
\end{tabular} & mean & st. Dev. & & & & \\
\hline MC & $1,98 \mathrm{E}+11$ & $5,04 \mathrm{E}+11$ & $3,56 \mathrm{E}+11$ & $9,26 \mathrm{E}+11$ & $4,34 \mathrm{E}+11$ & $9,31 \mathrm{E}+11$ & $3,36 \mathrm{E}+11$ & $6,70 \mathrm{E}+11$ & & & & \\
\hline LDC & $5,02 \mathrm{E}+02$ & $9,46 \mathrm{E}+02$ & $5,07 \mathrm{E}+02$ & $9,70 \mathrm{E}+02$ & $5,24 \mathrm{E}+02$ & $9,87 \mathrm{E}+02$ & $5,33 \mathrm{E}+02$ & $1,02 \mathrm{E}+03$ & $4,42 \mathrm{E}+08$ & $1,01 \mathrm{E}+08$ & & \\
\hline STTR & $4,13 \mathrm{E}+01$ & $4,56 \mathrm{E}+01$ & $5,20 \mathrm{E}+01$ & $6,48 \mathrm{E}+01$ & $4,16 \mathrm{E}+01$ & $5,15 \mathrm{E}+01$ & $4,25 \mathrm{E}+01$ & $5,65 \mathrm{E}+01$ & & & & \\
\hline INF & $9,24 \mathrm{E}+00$ & $5,19 \mathrm{E}+00$ & & & & & $6,32 \mathrm{E}+00$ & $4,76 \mathrm{E}+00$ & $-2,76 \mathrm{E}+10$ & $2,72 \mathrm{E}+10$ & & \\
\hline RINT & $3,74 \mathrm{E}+00$ & $8,08 \mathrm{E}+00$ & $9,40 \mathrm{E}+00$ & $7,07 \mathrm{E}+00$ & $4,50 \mathrm{E}+00$ & $8,23 \mathrm{E}+00$ & $4,63 \mathrm{E}+00$ & $7,79 \mathrm{E}+00$ & $9,64 \mathrm{E}+09$ & $1,57 \mathrm{E}+10$ & & \\
\hline GDP & $3,78 \mathrm{E}+00$ & $3,25 \mathrm{E}+00$ & & & & & $4,49 \mathrm{E}+00$ & $3,45 \mathrm{E}+00$ & $1,43 \mathrm{E}+10$ & $3,36 \mathrm{E}+10$ & & \\
\hline CII & $1,04 \mathrm{E}+00$ & $1,29 \mathrm{E}+00$ & $8,70 \mathrm{E}-01$ & $1,39 \mathrm{E}+00$ & $5,66 \mathrm{E}-01$ & $1,52 \mathrm{E}+00$ & & & & & & \\
\hline VA & & & & & & & & & $-3,82 \mathrm{E}+11$ & $1,71 \mathrm{E}+11$ & & \\
\hline PV & $-1,50 \mathrm{E}-01$ & $8,07 \mathrm{E}-01$ & $-2,23 \mathrm{E}-01$ & $7,96 \mathrm{E}-01$ & $-2,84 \mathrm{E}-01$ & $7,78 \mathrm{E}-01$ & $-3,05 \mathrm{E}-01$ & $6,86 \mathrm{E}-01$ & & & & \\
\hline $\mathrm{CC}$ & & & $-1,13 \mathrm{E}-01$ & 6,87E-01 & $-1,63 \mathrm{E}-01$ & $6,93 \mathrm{E}-01$ & $-1,67 \mathrm{E}-01$ & $6,96 \mathrm{E}-01$ & & & & \\
\hline $\mathbf{R}^{2}$ & & 45 & & 52 & 0, & & & 65 & 0,5 & 46 & & \\
\hline $\operatorname{adj.} \mathbf{R}^{2}$ & & 29 & & 4 & 0, & 43 & & 53 & 0,4 & 51 & & \\
\hline F Test & & 77 & 4, & 37 & 4, & 71 & 5,7 & 75 & 5,7 & 76 & & \\
\hline
\end{tabular}

Table 1 Descriptive Statistics

The effects of Portfolio equity, net inflows are found to be significant for the years 2002, with a t-value of 4.304. It is the only significant factor for that year. Equity inflows are so influential on market capitalization that it is removed from the regressions after the first year to have a better picture for the remaining factors. High correlation between net inflows and market capitalization also inflates the variance. Stocks traded, Turnover Ratio is found to be significant for the years 2003 through 2011 in a row however, and significance varies from 1 $\%$ to $10 \%$. This study provides evidence those countries that aim to enhance their market capitalization, have to increase stocks traded in their market. It may be deducted that Investors prioritize the ability to find a counter party and/or to convert their investments into cash quickly at fair prices.

Number of Listed domestic companies in a market is another determinant of market capitalization for the years 2004, 2005, 2010, 2011 and 2012 with t-statistics of 2,593, 2,134, 2,086, 2,232 and 4,392 respectively. It may be important to note that number of investment options markets provide to investors are essential in terms of market capitalization and by the time, the significance have increased as this factor is the only factor in 2012.

Foreign direct investment, net inflows are excluded from the independent variables list most of the time to overcome multicollinearity but for the years 2004 and 2005, variance inflator factor of the variable allowed us to incorporate its data into the model and Foreign direct investment, net inflows are found to be significant for the year 2005 with a t-statistic of 3.91. Either portfolio equity or foreign direct investments are significant factors affecting market capitalization rates. Intuitively, foreign funds broaden the base for these markets. In order to increase market capitalization, countries should seek ways to attract foreign capital.

Annual GDP growth has explained the change in market capitalisation for the years 2006, 2007 and 2011 with t-statistics of 2,030, 3,321 and 1,744. This variable was excluded from the list for three years due to multicollinearity concerns. Growth in an economy may attract investors tracking higher returns arising from higher growth rates. 
Voice and Accountability is found to be significant in 2012 with a t-statistic of $-2,233$. This study failed to Show evidence for the significance of Inflation, Real interest rates, The Chinn-Ito Index, Political Stability and Absence of Violence/Terrorism and Control of Corruption on Market Capitalization.

\begin{tabular}{|c|c|c|c|c|c|c|c|c|c|c|c|c|}
\hline Years & & PENI & FDI & LDC & STTR & INF & RINT & GDP & $\begin{array}{l}\text { KAOP } \\
\text { EN } \\
\end{array}$ & VA & PC & $\mathrm{CC}$ \\
\hline \multirow{2}{*}{2002} & $\mathrm{t}$ & $4,304^{* * * *}$ & & 0,358 & 1,542 & $-0,128$ & $-1,105$ & $-0,03$ & $-1,485$ & & 0,092 & 0,93 \\
\hline & Sig. & 0 & & 0,723 & 0,136 & 0,899 & 0,28 & 0,976 & 0,15 & & 0,928 & 0,361 \\
\hline \multirow{2}{*}{2003} & $\mathrm{t}$ & & & 0,829 & $2,422^{* * *}$ & & $-0,073$ & \begin{tabular}{|l}
0,753 \\
\end{tabular} & $-1,204$ & & $-0,138$ & 0,284 \\
\hline & Sig. & & & 0,414 & 0,022 & & 0,942 & 0,458 & 0,239 & & 0,891 & 0,778 \\
\hline \multirow{2}{*}{2004} & $\mathrm{t}$ & & 0,611 & $2,593 * *$ & $1,878^{*}$ & 0,394 & 0,47 & & $-1,519$ & & 0,864 & 1,15 \\
\hline & Sig. & & 0,546 & 0,015 & 0,072 & 0,697 & 0,642 & & 0,141 & & 0,396 & 0,261 \\
\hline \multirow{2}{*}{2005} & $t$ & & $3,910^{\text {**** }}$ & $2,134 * *$ & $2,818^{* * * *}$ & 0,16 & 0,907 & \begin{tabular}{|l|}
$-0,377$ \\
\end{tabular} & $-1,188$ & & & 0,28 \\
\hline & Sig. & & 0,001 & 0,042 & 0,009 & 0,875 & 0,373 & 0,709 & 0,245 & & & 0,782 \\
\hline \multirow{2}{*}{2006} & $\mathrm{t}$ & & & 1,027 & $2,329^{\text {*⿻: }}$ & $-0,746$ & 0,687 & $2,030 *$ & $-1,472$ & & 0,155 & 0,147 \\
\hline & Sig. & & & 0,314 & 0,028 & 0,463 & 0,498 & 0,053 & 0,153 & & 0,878 & 0,884 \\
\hline \multirow{2}{*}{2007} & $\mathrm{t}$ & & & 0,786 & $3,837^{\text {**का }}$ & $-1,167$ & $-0,37$ & $3,321^{3 * * 4}$ & $-0,935$ & & 0,034 & 0,091 \\
\hline & Sig. & & & 0,439 & 0,001 & 0,255 & 0,715 & 0,003 & 0,359 & & 0,973 & 0,928 \\
\hline \multirow{2}{*}{2008} & $\mathrm{t}$ & & & 0,658 & $1,890^{*}$ & $-1,228$ & $-0,374$ & 1,542 & $-1,636$ & & 0,441 & \\
\hline & Sig. & & & 0,517 & 0,071 & 0,231 & 0,711 & 0,136 & 0,115 & & 0,663 & \\
\hline \multirow{2}{*}{2009} & $t$ & & & 0,817 & $3,561^{\text {**** }}$ & & 1,181 & & $-1,353$ & & 0,918 & $-0,222$ \\
\hline & Sig. & & & 0,422 & 0,002 & & 0,249 & & 0,189 & & 0,368 & 0,826 \\
\hline \multirow[t]{2}{*}{2010} & $\mathrm{t}$ & & & $2,086 * *$ & $3,134^{* * * *}$ & & 0,942 & & $-1,292$ & & 0,608 & $-0,533$ \\
\hline & Sig. & & & 0,048 & 0,005 & & 0,356 & & 0,209 & & 0,549 & 0,599 \\
\hline \multirow[t]{2}{*}{2011} & $\mathrm{t}$ & & & $2,232 * *$ & $4,023^{\text {**** }}$ & $-0,302$ & 1,392 & $1,744 *$ & & & 0,193 & $-0,968$ \\
\hline & Sig. & & & 0,036 & 0,001 & 0,765 & 0,178 & 0,095 & & & 0,849 & 0,344 \\
\hline \multirow[t]{2}{*}{2012} & $\mathrm{t}$ & & & $4,392^{* * *}$ & & $-1,012$ & 0,614 & 0,425 & & $-2,233^{* *}$ & & \\
\hline & Sig. & & & 0 & & 0,322 & 0,545 & 0,674 & & 0,035 & & \\
\hline
\end{tabular}

$* * * \% 1$ level of significance $* * \% 5$ level of significance $* \% 10$ level of significance

Table 2 Annual Regression Results

\section{Conclusion}

Developed Countries and some developing countries enjoy relatively higher market capitalization as when they have higher capitalization; they may have access to financing. Countries that lack the adequate market capitalization should review factors that have an impact on it. Advancement in the positively affecting factors and mitigation of the adverse factors may help these countries to converge to the succeeding countries.

Number of Stocks traded in a market constantly affects the market capitalization in our findings and foreign funds play a critical role in market capitalization as well. To coax foreign investors, countries may aim to improve conditions and accountability may play a vital role. Growth rates may also attract foreign and domestic investors but higher market capitalization will lead to higher growth rates and higher rates will probably trigger new investments in these markets.

Developing Markets shall focus on the factors influencing market capitalization and keep in mind that these factors vary by time depending on the financial, social and political climate.

Possible ways to attract foreign investments in Eurasian markets may be provided by creating awareness for these markets; foreign investors should see these markets as a sound alternative for the markets they participate. This can be achieved by offering attractive options that have similar risk and return profile compared to the existing options foreign investors exercise. Breadth of a market, number of firms in an exchange, may not be influential in investment decisions as quality of the firms may have a priority. Thus, lack of firms that have sufficient market capitalization, stable dividends payout patterns or the existence of the of likelihood that the firm will have a stable dividend payout pattern in the near future may cause foreign investors to refrain from investing in these markets as well as the risks pertain to these investment.

\section{References}

- $\quad$ Atje, R., Jovanovic, B., 1993, Stock Markets and Development, European Economic Review 37, $632-640$.

- $\quad$ Bae, K. H., Bailey, W., Mao, C.X., 2006, Stock Market Liberalization and the Information Environment, Journal of International Money and Finance 25, 404-428.

- Baumol, W. J., 1986. Productivity, Growth, Convergence, and Welfare: What the Long Run Data Show, American Review 76, 1072-1085. 
- Choong, C., Baharumshah, A.Z., Yusop, Z., Habibullah, M.S., 2010, Private Capital Flows, Stock Market and Economic Growth in Developed and Developing Countries: A Comparative Analysis, Japan and The World Economy 22, 107-117.

- Clark J., Berko E., 1996, Foreign Investment Fluctuations and Emerging Market Stock Returns: The Case Of Mexico, Federal Reserve Bank of New York Research Paper No.9635, 1-35.

- Das D. K. 2014, Growth, integration and trends in equity markets in Asia, Asia Pacific Business Review, Vol. 20, No. 2, 286-301.

- $\quad$ Fung. M.K., 2009, Financial Development and Economic Growth: Convergence or Divergence? Journal of International Money and Finance 28, 56-67.

- $\quad$ Hussain, M.M., Rehman, M. Z., Rza I., 2012, A Relationship between Stock Market Development and Economic Growth; A Case Study on Pakistani Stock Exchange, International Journal of Management and Innovation 4, 54-61.

- $\quad$ Levine, R., Zervos, S., 1998. Stock Markets, Banks and Economic Growth. American Economic Review 88, 537-558.

- Merton, R.C., 1987, A simple Model of Capital Market Equilibrium with incomplete Information, Journal of Finance 42, 483-510.

- Narayan, P.K., Mishra S., Narayan S., 2011, Do Market Capitalization and Stocks Traded Converge? New Global Evidence, Journal of Banking and Finance 35, 2771-2781.

- $\quad$ Schatzberg, J.D., Reiber. R.P., 1992, Extreme Negative Information and the Market Adjustment Process: the Case of Corporate Bankruptcy, Quarterly Journal of Business and Economics 31, 3-21.

- Tillmann, P., 2013, Capital Inflows and Asset prices: Evidence from Emerging Asia, Journal of Banking and Finance 37, 717-729.

- Todea, A., Pleşoianu, A., 2013, The Influence of foreign Portfolio Investment on Informational Efficiency: Emprical Evidence from Central and Eastern European Stock Markets, Economic Modeling 33, 34-41.

- WB, World Bank Data, data.worldbank.org

- Chinn-Ito Index, 2014, http://web.pdx.edu/ ito/Chinn-Ito_website.htm 